\title{
Innovative technology of obtaining organic marble beef
}

\author{
V. S. Kozyr \\ izkzoo3337@gmail.com \\ State Institution "The Institute of Grain Crops NAAS", \\ 14 V. Vernadsky str., Dnipro, 49009, Ukraine
}

The aim was to develop an innovative technology for obtaining high-quality organic marble beef. In the experimental farm "Polyvanivka" of the Institute of Grain Crops NAAS the cultivation of bulls of the gray Ukrainian breed up to 30 months of age has been organized using fodder which is traditional for steppe zone of Ukraine. The work has been performed according to the research program of the National Academy of Agrarian Sciences of Ukraine no. 37 "System of work in populations and conservation of biological diversity of genetic resources of farm animals" ("Preservation of breed gene pool"). The expediency of organic production of high-quality marble beef obtained in the steppe zone of Ukraine from gray Ukrainian cattle has been proven. This breed has such economically useful features as the duration of production use, longevity, high growth energy (stable average daily gain over $1 \mathrm{~kg}$ ), and the conversion of diet into products (feed consumption is $70-80 \mathrm{MJ}$ per $1 \mathrm{~kg}$ of growth) correlating with the age of the animal, slaughter rates $(>60 \%$, meat content is $>4 \mathrm{~kg}$ per $1 \mathrm{~kg}$ of bones, hard skin is $>30 \mathrm{~kg}$ which belongs to the category of bull production). We have found that it is necessary to determine the cattle fatness not by subcutaneous fat which has no dietary value, but by the beef marbling as a sign of its quality which takes into account the presence of intramuscular and intermuscular fat including unsaturated fatty acids, vitamins $A$ and $D$, as well as the amount of protein and moisture and taste and culinary features of the carcass flesh, such as tenderness, juiciness and aroma. This meets the requirements of the consumer. The proposals based on the results of research on technological changes in animal husbandry promote the development of meat cattle breeding and are of great economic importance for strengthening the health of the population and food safety in Ukraine.

Key words: breed, bulls, age, growth energy, live weight, slaughter rates, beef, organic products, muscle, adipose tissue, marble meat, quality

Beef always was and will be one of the staple foods for humans. The medical norm of beef consumption is $31 \mathrm{~kg}$ per year. In Ukraine it was actually consumed less than $10 \mathrm{~kg}$ in 2020 [8]. In order to increase livestock productivity and make a large profit, most livestock enterprises introduce intensive production technologies using growth stimulants and even interfere in the animal genome. Such beef does not bring the expected benefits to the consumer who wants it to be environmentally friendly, tender, fragrant, juicy.

Therefore, scientists have developed an alternative concept and proposed the term "organic products", the main feature of which is the valuable biological quality and health properties obtained in the absence of chemicals and veterinary drugs [1]. In recent years, the standard of organic animal husbandry has been spreading around the world, based on closed agricultural systems and minimal use of energy sources.
In Ukraine such production also doubles every year, both in terms of production and the number of enterprises that conduct and certify the industry as organic. This is facilitated by the demand for such products both in the domestic market and for export. In accordance with the Program of Harmonious Development of the country in the XXI century, the initiative group "Agro-Organic Club" has developed a project of environmentally friendly and competitive agriculture, which maintains the balance of the environment and clean food.

The resolutions of the Council of the European Union set out the principles of organic animal husbandry, which provides for loose housing with maximum access to pastures, low livestock load per unit area, taking into account its ethological features, creating comfortable conditions for growing (microclimate, litter), concentrated feed in the diet for nutrition should not exceed $40 \%$ and it is allowed to use vitamin and mineral supplements 
(premixes) only when the need for them can not be met by natural feeds and pastures (the use of artificial amino acids, hormonal drugs, stimulants, extracted components of feed and antibiotics is generally prohibited).

Many farmers in France, Canada, Switzerland, the United States and other countries raise livestock in accordance with these requirements [4]. Of course, the implementation of these principles leads to some increase in production costs. In some agricultural enterprises in Germany, Great Britain, Austria, Poland, the cost of such beef has increased [6].

However, the demand for it increases every year and economic efficiency increases due to higher sales prices. Despite the higher costs, organic livestock production in Ukraine is also becoming especially relevant because a large share of beef, unfortunately, comes to the market from dairy cattle which is not the highest quality [11]. At the domestic legislative level, the Ukrainian Parliament has adopted a relevant law that defines the legal, economic, social and organizational framework for organic agriculture (including livestock) for the receipt, processing, certification, transportation, storage and sale of products and raw materials, aimed at protecting public health and the environment [7, 9]. Today there are already agricultural formations in Dnipropetrovsk, Kyiv, Poltava and other regions of Ukraine where these requirements are met. But the prices have not yet been settled.

\section{Materials and Methods}

In order to confirm this, we organized the cultivation of gray Ukrainian breed bulls $(n=15)$ up to 30 months in the experimental farm "Polyvanivka" of the Institute of Grain Crops NAAS in compliance with the requirements of organic production. Slaughter of animals was carried out at one and a half-, two- and 2.5 years of age for 5 heads. Zootechnical, statistical, biometric research methods were used.

\section{Results and Discussions}

Particular attention was paid to the amount and topography of fat because age-related deviations in the presence of moisture, protein and dry matter in the carcasses were natural. The meat ratio (the ratio of pulp mass to bone mass) ranged from 5.1 at 18 months of age to 4.8 at 30 months of age.

The quality of the pulp was determined by its fat, protein and moisture content. The process of fat deposition in the body of cattle occurred simultaneously and unevenly throughout the body of the animal. Intramuscular fat, which contains unsaturated fatty acids, vitamins $A$ and $D$, provides the greatest nutritional, dietary value and marbling. They give beef tenderness, juiciness, aroma and good culinary and technological qualities.
Marble beef is valued for nitrogenous extractives, biotin, pantothenic acid, essential amino acids which increase the secretory function of the human gastrointestinal tract and improve digestibility. The content of these substances is higher than in other types of meat (including beef dairy breeds). The presence of trace elements in such meat inhibits the formation of cholesterol in the blood [12].

Beef is called marbled because of the fat between the muscle fibers so the muscles resemble a pattern of marble with light layers. The degree of marbling is determined by cutting the longest muscle of the back in the carcass between 12 and 13 ribs: the more intramuscular fat there is, the higher is the marbling. The following categories of marbling are accepted in the world in ascending order: select, choice, prime. Each of them also has ascending subcategories " $\mathrm{A}$ " and " $\mathrm{B}$ ", in which the marbling is determined from 1 to 5 points (the highest quality "A5" is top of the top).

All the fat in the body of cattle is successively deposited first of all under the skin, then around the kidneys, stomach, intestines, heart and only after that in the middle and between the lumbar muscles which are less "working". It has a yellowish or grayish color, melts during cooking (temperature processing) giving the meat juiciness, tenderness and aroma [3].

The cattle breed, both imported and domestic which include the gray Ukrainian, should be specialized in the direction of meat productivity. It is suitable for such economically useful features as the duration of production use, longevity, high growth energy (for fattening up to $1200 \mathrm{~g} /$ day), proportionality of the physique, the harmony of muscle development (uniformity index 0.74 ), at 30 months of age bulls reach live weight up to $700 \mathrm{~kg}$, amino acid value of protein in beef.

Livestock technology plays an important role in the production of organic marble beef. More than 120 different technologies are known [10]. Each of them has its own characteristics and the right to exist. But they also have common elements. At the same time, the international scientific community is in need of developing new environmentally friendly technologies for livestock production. In this regard, in the steppe zone of Ukraine we have developed, tested and implemented low-cost ethologically-based organic technology for raising cattle for meat. Its significance lies in the fact that throughout the spring-summer-autumn period (from March to November) the animals are kept free of charge 24 hours a day without feeding with compound feeds on a large fenced area (2 hectares of natural pastures per 1 animal) without shepherds. The use of any premises, equipment (fuels and lubricants), electricity is excluded.

At the same time, labor costs per 1 quintal of growth are 3-4 people/hour, which is 10 times less than the average in the Dnipropetrovsk region. Animals up to 8 months were raised on suckling with their mothers, then on free grazing to a live weight of $300-350 \mathrm{~kg}$, and then transferred to a feeding area or on a leash (or in 
a separate machine) to limit movement, which leads to loss growth (including intramuscular fat). At this time, more carbohydrates (corn, barley, special feeds) were added to the feeding rations including biologically active and aromatic substances [5].

Naturally, the rate of fat synthesis in cattle with age gradually outpaced muscle tissue, its total amount in the body increased, including intra- and intermuscular. Its mass in the flesh of the carcass also increased, which was a characteristics of the beef marbling (table).

Table. Marbling of meat of gray Ukrainian breed bulls

\begin{tabular}{|c|c|c|c|}
\hline \multirow{2}{*}{ Indicator } & \multicolumn{3}{|c|}{ Age, months } \\
\hline & 18 & 24 & 30 \\
\hline Number of animals, $n$ & 15 & 10 & 5 \\
\hline Carcass weight, kg & $323.5 \pm 3.83$ & $359.6 \pm 5.61$ & $380.0 \pm 9.14$ \\
\hline $\begin{array}{l}\text { Mass of pulp } \\
\text { in the carcass, } \mathrm{kg}\end{array}$ & $270.8 \pm 2.94$ & $296.2 \pm 4.73$ & $314.6 \pm 8.71$ \\
\hline $\begin{array}{l}\text { Proportion of pulp } \\
\text { in the carcass, } \%\end{array}$ & 83.71 & 83.09 & 82.80 \\
\hline $\begin{array}{l}\text { Mass of fat } \\
\text { in the carcass, kg }\end{array}$ & $33.6 \pm 1.40$ & $41.7 \pm 1.72$ & $49.0 \pm 1.61$ \\
\hline $\begin{array}{l}\text { Proportion of fat } \\
\text { in the carcass, } \%\end{array}$ & $10.4 \pm 1.11$ & $11.6 \pm 1.30$ & $12.9 \pm 1.41$ \\
\hline $\begin{array}{l}\text { Mass of internal } \\
\text { muscle fat, kg }\end{array}$ & $18.8 \pm 1.40$ & $22.7 \pm 1.72$ & $27.0 \pm 1.64$ \\
\hline $\begin{array}{l}\text { Proportion of internal } \\
\text { muscle fat: } \\
\text { in the carcasses, \% }\end{array}$ & $5.8 \pm 1.08$ & $6.3 \pm 1.21$ & $7.1 \pm 1.30$ \\
\hline in the pulp, $\%$ & $6.9 \pm 1.60$ & $7.7 \pm 1.70$ & $8.6 \pm 2.11$ \\
\hline $\begin{array}{l}\text { Caloric content } \\
\text { of } 1 \mathrm{~kg} \text { of pulp, MJ }\end{array}$ & $9.0 \pm 0.81$ & $9.8 \pm 0.90$ & $14.0 \pm 1.32$ \\
\hline Pulp acidity, $\mathrm{pH}$ & $6.5 \pm 0.10$ & $6.0 \pm 0.10$ & $5.9 \pm 0.10$ \\
\hline Pulp tenderness, \% & $0.48 \pm 0.02$ & $0.43 \pm 0.02$ & $0.40 \pm 0.01$ \\
\hline Pulp boiling, \% & $35.7 \pm 1.80$ & $33.6 \pm 1.61$ & $31.8 \pm 1.70$ \\
\hline
\end{tabular}

But the proportion of the most valuable flesh in the carcass remained almost stable $(2.5 \%)$ for 2.5 year of the bull's life, and the mass of intramuscular fat accumulated and was heavier than all the fat in the carcass. Marbling and caloric content of beef correlate with the age of the animals. Compared to 18 months of age, the total amount of fat increased by $22 \%$, and in the flesh by 1.5 times.

The coefficient of marbling of beef (the ratio of the mass of intramuscular fat to the mass of flesh) also increased more intensively, and this attracts the consumer even with increasing its caloric content because the juiciness, aroma and tenderness of meat remain optimal without changes and culinary qualities (boiling) are improving. Normal acidity indicates the possibility of long-term storage.
It has been proven that it is better to raise bulls than heifers. They differ in the physical and biochemical structure of all tissues and the energy of growth - in the body of bulls less moisture and more dry matter; as a result, the meat is more complete. They have higher viability. It is advisable to slaughter them at the age of 2-2.5 years. The slaughter yield is $60 \%$ or more, and the ratio of total fat to protein - 1.5-2.0 that is liked by the consumer.

Veal meat of bulls up to one year old has almost no intramuscular fat layers and cannot be marbled. This is due to the fact that in a young body the synthesis of muscle tissue (protein) precedes the synthesis of adipose tissue, and with age, on the contrary, the synthesis of adipose tissue gradually outstrips muscle growth and, thus, the salting of the carcass. Veal is a dietary product that is especially useful for children and people with impaired gastrointestinal tract.

Marble meat matures better in bran and lasts at least two weeks at $t 0 \ldots+2^{\circ} \mathrm{C}$ under the action of biochemical processes. Fermentation destroys the fibers, the meat becomes tender and closer to the "reference protein", the composition of which is proposed by the FAO/WHO balanced in amino acid composition.

In international practice, two systems of evaluation of marble meat have been acquired: American (BMS - 12-point standard) and Japanese (5-point scale). The Australian beef rating system is based on similar principles but defines only three categories - from 3 to 5 stars. European scientists, including Ukrainian, conduct research to determine the limit parameters of the composition of organic marble beef [2].

In Ukraine, more than 100 farms operate on the principles of organic production in Dnipropetrovsk, Zaporizhia, Donetsk, Kirovohrad and other regions, who understand that maintaining the existing high fertility of arable land is possible only through organic and not chemical fertilizers. The obtained products become a special national feature of our state among the countries of the international community.

Organic livestock is more natural for animals. High concentrations of livestock in limited areas and unbalanced feeding reduce the resistance and productivity of animals and product quality, which has a negative impact on the economic efficiency of the industry. Therefore, technological changes in beef production are very urgent.

\section{Conclusions}

1. Gray Ukrainian breed with observance of the corresponding technology gives organic marble beef.

2. Different specific gravity of intramuscular fat of carcass flesh allows to classify beef by marbling. Determining the fattening of cattle for irrigation does not meet consumer demand and needs to be clarified in the direction of determining the amount of intramuscular fat.

3 . The introduction of the marbling coefficient will help accelerate the development of beef cattle breed- 
ing and more fully meet the needs of the population in high-quality organic beef, which is very important in creating food security of the state.

\section{Prospects for further research}

Further work will be aimed at conducting research on fattening and meat qualities, as well as physicochemical properties and chemical composition of muscle tissue of young cattle of the Ukrainian gray breed, taking into account their belonging to different genealogical lines. This is an important aspect of changing the technology of keeping and feeding animals in the direction of meat productivity, as well as the choice of direction for further breeding work.

1. Antonenko G, Hrebel L. Calf breeding technologies. Agribusiness Today. 2011; 7: 36-39. (in Ukrainian)

2. Artemova O. Humanism as a component of the quality of livestock products. Kyiv, Mega-Poligraf, 2007: 1-3. (in Ukrainian)

3. Gotsiridze N., Tortladze L. Determination of the biological value of beef. Zootechnics. 2001; 8: 31-32. (in Russian)
4. Honcharenko I. Meat cattle breeding of the leading countries of Europe. Livestock Ukraine. 1997; 4: 30 p. (in Ukrainian)

5. Law of Ukraine no. 2496-VIII from 10.08.2018. On main principles and requirements to organic production, its circulation and marking. With changes made in accordance with the Law no. 2740-VIII from 06.06.2019. Kyiv, 2018. Available at: https://zakon.rada.gov.ua/ laws/show/2496-19\#Text (in Ukrainian)

6. Legoshin GP. Comprehensive assessment of meat productivity, quality of carcasses and meat of young cattle. Animal Science. 2009; 9: 30-32. (in Russian)

7. Medvedev AY, Lynnyk VS. Theoretical and practical substantiation of energy-saving technology of beef production with year-round use of canned feed. Lugansk, Elton, 2011: 222 p. (in Ukrainian)

8. Melnyk YV. Formation of meat productivity in animals of different breeds of cattle bred in Ukraine. Korsun-Shevchenkivsky, 2010: 400 p. (in Ukrainian)

9. Mykhalchenko S. Conversion of nutrients into meat productivity. Livestock Ukraine. 2011; 7: 31-33. (in Ukrainian)

10. Oliynyk S. Output of food protein from bulls under the different growing technologies. Collection Sci. Works Vinnytsia Nat. Agr. Univer. Agricult. Sci. 2010; 5 (45): 204-207. Available at: http:// agrojournal.vsau.org/files/pdfa/1222.pdf (in Ukrainian)

11. Organic Standard. A certification company. Available at: https:// organicstandard.ua (in Ukrainian)

12. Ukrainian beef market. Effective Animal Husbandry. 2008; 3 (27): 6-7. (in Ukrainian)

\section{Інноваційна технологія одержання органічної мармурової яловичини}

B. С. Козир

izkzoo3337@gmail.com

Державна установа «Інститут зернових культур НААН», вул. В. Вернадського, 14, м. Дніпро, 49009, Україна

Мета - розробити інноваційну технологію одержання високоякісної органічної мармурової яловичини. У дослідному господарстві «Поливанівка» Інституту зернових культур НААН організували вирощування бугайців сірої української породи великої рогатої худоби до 30-місячного віку з використанням традиційних кормів степової зони України. При цьому використовували зоотехнічні, статистичні, біометричні методи досліджень. Роботу виконано згідно з програмою наукових досліджень Національної академії аграрних наук України № 37 «Система роботи в популяціях і збереження біологічного різноманіття генетичних ресурсів сільськогосподарських тварин» («Збереження генофонду порід»). Доведено доцільність органічного виробництва високоякісної мармурової яловичини, одержаної в умовах степової зони України від сірої української худоби, яка має такі господарсько корисні ознаки, як тривалість виробничого використання (десять і більше отелень), довгорослість (понад п'ять років), високі енергію росту (стабільні середньодобові прирости живої маси понад 1 кг) та конверсію раціону в продукцію (витрати кормів-70-80 МДж на 1 кг приросту), корелюючи з віком тварин, забійні показники (понад 60\%, коефіцієнт м'ясності понад 4 кг на 1 кг кісток, важкі шкіри — понад 30 кг, які належать до категорії «бичина»). Доведено необхідність визначення вгодованості великої рогатої худоби не за підшкірним жиром (поливом), який не має харчової цінності, а за мармуровістю яловичини як ознаки якості, яка враховує наявність внутрішньом'язового і міжм'язового жиру, до складу якого входять ненасичені жирні кислоти, вітаміни A i D, а також кількість білка і вологи, та смакові і кулінарні особливості м'якоті туші - ніжність, соковитість і аромат. Це відповідає вимогам споживача. Пропозиції, сформульовані на підставі одержаних результатів досліджень, за технологічними змінами вирощування тварин сприяють розвитку м'ясного скотарства і мають велике народногосподарське значення щодо зміцнення здоров'я населення і продовольчої безпеки України.

Ключові слова: порода, бугайці, вік, енергія росту, жива маса, забійні показники, яловичина, органічна продукція, м'язова, жирова тканини, мармуровість, якість

Kozyr VS. Innovative technology of obtaining organic marble beef

Biol. Tvarin. 2021; 23 (2): 8-11. DOI: 10.15407/animbiol23.02.008. 